\section{Revista de la \\ Universidad del Thulia}

Fundada en 1947 por el Dr. Jesúns Enrique Lossada

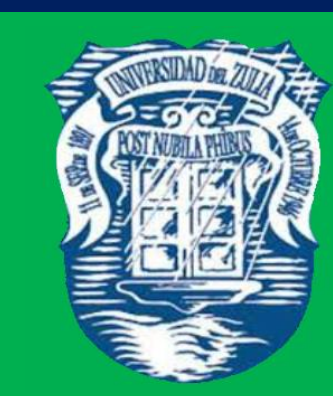

Ciencias del

Algreo

Ingemieria

y Teemología

\section{Aกัต 11 No 29}

Enero - Abril 2021

Tercera Época

Maracaibo-Venezuela 


\title{
Improving the cold flow properties of marine diesel fuel using centrifugation
}

\author{
Nikolay S. Yakovlev* \\ Vyacheslav G. Agaev * \\ Evgeniy O. Zemlyansky*
}

ABSTRACT

The possibility of improving the low-temperature properties of marine diesel fuel of the Antipinsky Refinery by dewaxing was studied. Paraffin was isolated from the fuel in a centrifuge in the presence of a depressant additive. The depressant additive is selected from a series of synthesized additives for depressant effectiveness. The influence of the centrifuge rotor speed, the additive content and the initial cooling temperature of the sample on the dewaxing parameters of the fuel was studied. The possibility of isolating the additive from the obtained paraffin concentrates is shown. The dewaxing products obtained under optimal conditions were studied. A paraffin concentrate product containing $40.03 \%$ solid paraffins was isolated from fuel. Paraffin was isolated from paraffin concentrate by dewaxing with a selective solvent. The cloud point and freezing point of paraffin were 30 and $29^{\circ} \mathrm{C}$, respectively. When converted to the original fuel, the amount of released paraffins was $7.3 \%$ of the $21 \%$ by weight contained in the original fuel. The fuel obtained at optimal parameters for low temperature properties corresponds to grade D of diesel fuel according to EN 590: 2009.

KEY WORDS: diesel fuel; low temperature properties; centrifuge; dewaxing; depressant additive.

*Industrial University of Tyumen, Volodarskogo, 38, Tyumen, Russia, 625000 kropchevasn@tyuiu.ru

Recibido: 26/12/2019

Aceptado: 29/01/2020 


\section{Mejora de las propiedades de flujo en frío del combustible diesel marino mediante centrifugación}

RESUMEN

Se estudió la posibilidad de mejorar las propiedades de baja temperatura del combustible diesel marino de la Refinería Antipinsky mediante el desparafinado. La parafina se aisló del combustible en una centrífuga en presencia de un aditivo depresor. El aditivo se selecciona de una serie de aditivos sintetizados para la efectividad del depresor. Se estudió la influencia de la velocidad del rotor de la centrífuga, el contenido de aditivos y la temperatura de enfriamiento inicial de la muestra en los parámetros de desparafinado del combustible. Se muestra la posibilidad de aislar el aditivo de los concentrados de parafina obtenidos. Se estudiaron los productos de desparafinado obtenidos en condiciones óptimas. Se aisló del combustible un producto concentrado de parafina que contenía 40,03\% de parafinas sólidas. La parafina se aisló del concentrado de parafina desparafinando con un disolvente selectivo. El punto de enturbiamiento y el punto de congelación de la parafina fueron 30 y $29^{\circ} \mathrm{C}$, respectivamente. Cuando se convirtió al combustible original, la cantidad de parafinas liberadas fue del $7,3 \%$ del $21 \%$ en peso contenido en el combustible original. El combustible obtenido en los parámetros óptimos para las propiedades de baja temperatura corresponde al grado D del combustible diesel de acuerdo con la norma EN 590: 2009.

PALABRAS CLAVE: combustible diesel; propiedades de baja temperatura; centrífugo; desparafinado; aditivo depresivo.

\section{Introduction}

This work deals with the production of diesel fuel with improved cold flow properties by dewaxing of marine diesel fuel without selective solvents. For this, the method of centrifuging the initial diesel fuel in a high-speed centrifuge was used. The method of dewaxing petroleum products using centrifugation has been known for a long time. Its use was limited to dewaxing of oils at Barisol-process plants. In Russia, the last Barisol-process plant was operated until the end of the $70 \mathrm{~s}$ of the last century (Chernozhukov, 1978). At this plant, a mixture of dichloroethane (80\%) and benzene was used as a solvent. The rotor speed of the centrifuges was $6300 \mathrm{rpm}$. Dichloroethane was also used, among other things, to increase the density difference between the liquid (oil + solvent) and solid (petrolatum with a small solvent content) phases. The performance indicators of such plants are inferior to the current ones that use ketone-aromatic solvents 
and vacuum filters. In addition, the centrifuges at a Barisol-process plant are non-tight, which affected the health of the staff. Attempts were made to dewax diesel fuels in centrifuges with a rotor speed of 4000 rpm (Agaev, Yakovlev, Schipanov, 2008). Modern centrifuges are advanced, the speed of rotation of their rotors is increased and they can be manufactured leak-tight. In this regard, the separation of intermediate products for the production of oils and diesel fuels in modern centrifuges becomes relevant. If positive results are obtained, dewaxing of oil products by solvent-free centrifugation will be a significant contribution to the dewaxing technology.

The cloud point (CP) and cold filter plugging point (CFPP) are the most difficult to achieve cold flow properties of diesel fuels (DF). One of the ways to improve the quality of diesel fuel according to these indicators is the method of partial dewaxing of diesel fuel in an electric field, which ensures the removal of high-melting-point $n$-alkanes $\mathrm{C}_{19+}$ from their composition (Agaev, Yakovlev, Zima, 2012; Yakovlev, Agaev, 2012; Agaev, Yakovlev, Stolbov, 2012; Yakovlev, Agaev, 2017). The advantage of this method is the dewaxing of diesel fuel without the use of solvents, which makes it economically advantageous. The method is characterized by positive values of the temperature effect of dewaxing and, therefore, does not require subcooling of raw materials. The disadvantage of the processes of electrical dewaxing of petroleum products is the need to use high-voltage electric fields, which complicates the equipment and makes its operation dangerous.

\section{Materials and Methods}

The marine diesel fuel of the Antipinsky Refinery (Tyumen) used in the work had the following properties: cloud point $-1^{\circ} \mathrm{C}$, pour point - minus $3^{\circ} \mathrm{C}$, density at $20^{\circ} \mathrm{C}$ $844 \mathrm{~kg} / \mathrm{m}^{3}$, viscosity at $20^{\circ} \mathrm{C}-6.9 \mathrm{~mm}^{2} / \mathrm{s}$, refractive index at $35^{\circ} \mathrm{C}-\mathrm{n}_{\mathrm{D}}^{35} 1.4640 ; 10 \%$ of diesel fuel boils off at $187^{\circ} \mathrm{C}, 50 \%$ - at $285^{\circ} \mathrm{C}, 90 \%$ - at $366^{\circ} \mathrm{C}$ and $96 \%$ - at $394^{\circ} \mathrm{C}$, content of hydrocarbons that formed a complex with urea $-21.0 \%$ wt. The content of fractions of $\mathrm{n}$-alkanes from their total amount in diesel fuel, \% wt.: $\Sigma C_{12-14}=23.31, \Sigma C_{15-18}=37.11$ and $\Sigma$ $\mathrm{C}_{19+}=39.58$. Marine diesel fuel is enriched with $\mathrm{n}$-alkanes with the number of carbon atoms from 10 to 22 , the maximum content falls on medium-melting-point $\mathrm{C}_{14-16}$ paraffins. The distribution of $\mathrm{n}$-alkanes in diesel fuel was determined on a Crystal 5000 chromatograph 
equipped with an MXT 2887 column $10 \times 0.53 \times 2.65$. The column is designed to separate $\mathrm{n}$ alkanes with carbon atoms from $C_{7}$ to $C_{45}$. The content of $n$-alkanes in the fuel was determined by peaks with automatic integration of their area on a computer using a special program. The volume of sample introduced into the column was $0.06 \mu l$. The temperature range was $0-300^{\circ} \mathrm{C}$, the rate of temperature rise was $5-10^{\circ} \mathrm{C} / \mathrm{min}$. The carrier gas was helium. The detector was flame ionization.

To increase the efficiency of centrifuging diesel fuel, the depressant additive DP5/17 was used, which at a dewaxing temperature ensured a decrease in the structural viscosity of the initial diesel fuel. The amidopolyformaldehyde depressant additive DP-5/17 was a condensation product of polyethylene polyamines (PEPA), stearic acid (SA) and formaldehyde (FA). The molar ratio of the starting reagents SA:PEPA:FA was 1.7:1.0:30.0. The additive was obtained according to the procedure described in (Agaev, Gultyaev, Yakovlev, 2007). The additive DP-5/17 was chosen taking into account its effectiveness from a series of synthesized additives of the same type with different ratios of the starting reagents (Table 1). Efficiency assessment was carried out by a combination of pour points (ASTM D97-05) and cloud points (ASTM D2500-05) of marine diesel fuel when additives were added to its composition in the range from 0.05 to $2.0 \%$ wt.

Table 1 - The pour point and cloud point of marine diesel fuel (MDF) with the introduction of depressant additives

\begin{tabular}{|c|c|c|c|c|c|c|c|c|c|}
\hline \multirow{3}{*}{ Additives } & \multicolumn{3}{|c|}{$\begin{array}{l}\text { Additives are synthesized } \\
\text { at a molar ratio of starting } \\
\text { reagents }\end{array}$} & \multicolumn{6}{|c|}{ Content of additives in MDF, \%wt. } \\
\hline & \multirow{2}{*}{ SA } & \multirow{2}{*}{ PEPA } & \multirow{2}{*}{ FA } & 0.00 & 0.05 & 0.1 & 0.5 & 1.0 & 2.0 \\
\hline & & & & \multicolumn{6}{|c|}{ MDF pour point $\left({ }^{\circ} \mathrm{C}\right)$} \\
\hline DP-7/16 & 1.7 & 1.0 & - & -3 & -7 & -16 & -20 & -25 & -12 \\
\hline DP-12/16 & 1.7 & 1.0 & 10.0 & -3 & -10 & -13 & -13 & -28 & -31 \\
\hline DP-25/16 & 1.7 & 1.0 & 2 & -3 & -12 & -21 & -24 & -24 & -28 \\
\hline DP-5/17 & 1.7 & 1.0 & 30.0 & -3 & -15 & -23 & -25 & -27 & -29 \\
\hline & & & & \multicolumn{6}{|c|}{ MDF cloud point $\left({ }^{\circ} \mathrm{C}\right)$} \\
\hline $\mathrm{DP}-7 / 16$ & 1.7 & 1.0 & - & 1 & 1 & 2 & 1 & 37 & 41 \\
\hline DP-12/16 & 1.7 & 1.0 & 10.0 & 1 & 1 & 3 & 1 & 19 & 36 \\
\hline DP-25/16 & 1.7 & 1.0 & 20.0 & 1 & 2 & 0 & 13 & 30 & 39 \\
\hline DP-5/17 & 1.7 & 1.0 & 30.0 & 1 & 0 & 0 & 11 & 27 & 30 \\
\hline
\end{tabular}

Designations: SA - stearic acid; PEPA - polyethylene polyamines; FA - formaldehyde.

Marine diesel fuel (MDF) dewaxing was carried out on a Thermo Scientific refrigeration centrifuge (Germany). The centrifuge provides temperature control in the 
working area in the range from 40 to minus $10^{\circ} \mathrm{C}$, and it is equipped with 6 test tubes with a volume of $50 \mathrm{ml}$ each with a total load of $300 \mathrm{ml}$. The speed of rotation of the centrifuge rotor is adjustable from 1000 to $9500 \mathrm{rpm}$. The initial DF or its mixture with a depressant additive was preliminarily subjected to heat treatment in a thermostat at $60^{\circ} \mathrm{C}$ until the raw mixture was completely dissolved. MDF or its mixture with an additive was cooled in a Lauda RP 855 cryostat to a centrifuging temperature of minus $10^{\circ} \mathrm{C}$. Next, MDF was transferred to a centrifuge, in the program of which the initial work parameters were preliminarily set: rotation speed of the centrifuge rotor, centrifuging temperature (minus $10^{\circ} \mathrm{C}$ ) and centrifuging time ( 15 minutes). At the end of centrifuging, the final temperature in the centrifuging tubes is measured. The final temperatures in the tubes due to friction of the centrifuge rotor with the surrounding air are noticeably higher than the initial temperatures in the tubes and the temperature set in the centrifuge. As a result of centrifuging, dewaxed diesel fuel (DDF) and paraffin concentrate (PC) are obtained. The yield of DDF, PC and losses are determined. For DDF, cloud point (ASTM D2500-05), pour point (ASTM D97-05), and refractive index (IRF-454B2M refractometer) at a temperature of $35^{\circ} \mathrm{C}$ were determined. For paraffin concentrate, the melting temperature and refractive index were determined at a temperature of $35^{\circ} \mathrm{C}$. The influence of the centrifuging parameters on the yield and quality indicators of the obtained products was evaluated - the cloud point and the refractive index of DDF. The cloud point $t_{c}$ of dewaxed diesel fuels, for reasons of simplicity and convenience, was chosen instead of the cold filter plugging point (CFPP) used for summer diesel fuel according to EN 590:2009. CFPP, as a rule, is lower than the cloud point of fuels, which with a margin ensures that DDF meets the requirements of GOST in terms of CFPP.

\section{Results}

Table 2 presents experimental data on the influence of the rotor speed of the centrifuge and the content of the depressant additive DP-5/17 in diesel fuel on the yield and the main indicator of the quality of diesel fuel - its cloud point. The rotor speed varied from 3000 to $9000 \mathrm{rpm}$. The content of the additive in the initial fuel ranged from $0.1 \%$ wt. up to $1.0 \%$ wt. 
Table 2 - Effect of marine diesel fuel centrifuging parameters on product yields and DDF cloud point

\begin{tabular}{|c|c|c|c|c|c|c|c|}
\hline \multirow{2}{*}{$\begin{array}{l}\text { No. of } \\
\text { exper } \\
\text { iment }\end{array}$} & \multicolumn{2}{|c|}{$\begin{array}{l}\text { Centrifuging } \\
\text { parameters }\end{array}$} & \multirow[b]{2}{*}{$\begin{array}{c}\boldsymbol{t}_{\boldsymbol{f}} \text { of } \\
\text { centrifuging, }{ }^{\circ} \mathrm{C}\end{array}$} & \multicolumn{3}{|c|}{$\begin{array}{l}\text { Yields of centrifuging } \\
\text { products, \%wt. }\end{array}$} & \multirow{2}{*}{$\begin{array}{l}\boldsymbol{t}_{\boldsymbol{c}} \text { of } \\
\mathrm{DDF}, \\
{ }^{\circ} \mathrm{C}\end{array}$} \\
\hline & $\omega_{r}, \mathrm{rpm}$ & $\begin{array}{l}\text { Content of } \\
\text { DP-5/17 in } \\
\text { MDF, \% wt. }\end{array}$ & & DDF & PC & Losses & \\
\hline 1 & 3000 & 0 & -4 & \multicolumn{4}{|c|}{ No product separation. } \\
\hline 2 & 4000 & 0 & -4 & 77.9 & 20.5 & 1.7 & -1 \\
\hline 3 & 5000 & 0 & -4 & 68.6 & 30.3 & 1.1 & -4 \\
\hline 4 & 6000 & 0 & -4 & 84.5 & 13.7 & 1.8 & -4 \\
\hline 5 & 7000 & 0 & -2 & 83.8 & 14.5 & 1.7 & -8 \\
\hline 6 & 8000 & 0 & -1 & 80.6 & 17.2 & 2.2 & -5 \\
\hline 7 & 9000 & 0 & 0 & 86.9 & 11.8 & 1.3 & -3 \\
\hline 8 & 3000 & 0.1 & -4 & 69.3 & 30.3 & 0.5 & -5 \\
\hline 9 & 4000 & 0.1 & -4 & 70.6 & 26.6 & 2.8 & -3 \\
\hline 10 & 6000 & 0.1 & -4 & 82.6 & 16.4 & 1.0 & -6 \\
\hline 11 & 7000 & 0.1 & -2 & 85.0 & 13.5 & 1.5 & -10 \\
\hline 12 & 8000 & 0.1 & -1 & 79.3 & 18.2 & 2.6 & -10 \\
\hline 13 & 3000 & 0.5 & -4 & 74.6 & 24.3 & 1.2 & -5 \\
\hline 14 & 4000 & 0.5 & -4 & 75.7 & 19.4 & 4.9 & -5 \\
\hline 15 & 5000 & 0.5 & -4 & 71.0 & 27.7 & 1.3 & -8 \\
\hline 16 & 6000 & 0.5 & -4 & 82.8 & 16.6 & 0.7 & -8 \\
\hline 17 & 7000 & 0.5 & -2 & 80.5 & 18.0 & 1.5 & -9 \\
\hline 18 & 8000 & 0.5 & -1 & 78.4 & 17.7 & 4.0 & -10 \\
\hline 19 & 9000 & 0.5 & 0 & 81.9 & 16.5 & 1.5 & -5 \\
\hline 20 & 5000 & 1.0 & -4 & 75.6 & 21.0 & 3.4 & -9 \\
\hline 21 & 7000 & 1.0 & -2 & 78.1 & 20.4 & 1.5 & -10 \\
\hline 22 & 8000 & 1.0 & -1 & 72.1 & 23.3 & 4.6 & -10 \\
\hline 23 & 9000 & 1.0 & 0 & 77.2 & 19.8 & 3.0 & -5 \\
\hline
\end{tabular}

Constant parameters: centrifuging time $\tau=15 \mathrm{~min}$; initial temperature of cooling of the DF sample before centrifuging $t_{\text {in }}=$ minus $10^{\circ} \mathrm{C}$; temperature of a cryostat integrated in a centrifuge $t_{c r}=$ minus $10^{\circ} \mathrm{C}$.

Abbreviations: PC - paraffin concentrate; $t_{f}-$ final centrifuging temperature; $\omega_{r}-$ centrifuge rotor speed, $r p m ; t_{c}$ of DDF - cloud point of DDF.

Centrifuging of marine diesel fuel (MDF) in the absence of a depressant additive (experiments No. 1-7) shows that in the range of rotor speeds from 5000 to $9000 \mathrm{rpm}$ there is a slight decrease in the cloud point of dewaxed diesel fuel (DDF) relative to the cloud point of the initial MDF. By the DDF yield and its cloud point, the best results are observed at a centrifuge rotor speed of $7000 \mathrm{rpm}$. The yield of DDF reaches $83.8 \% \mathrm{wt}$., and its cloud 
point is minus $8^{\circ} \mathrm{C}$. The temperature difference between the temperature set in the centrifuge and the cloud point of the resulting DDF is minus $2^{\circ} \mathrm{C}$. When the speed of rotation of the centrifuge rotor is $8000-9000 \mathrm{rpm}$, the cloud point of DDF increases. At a rotor speed of $3000 \mathrm{rpm}$, dewaxing of the initial fuel does not occur. A feature of the MDF dewaxing by the centrifuging method is the increase in the final temperature in the centrifuge from minus $10^{\circ} \mathrm{C}$ (the temperature set in the centrifuge) to $0^{\circ} \mathrm{C}$. Moreover, the higher the temperature, the higher the rotation speed of the centrifuge rotor due to its friction with air. The cloud point of DDF at a rotor speed of $7000-8000 \mathrm{rpm}$, which is minus 5 - minus $8^{\circ} \mathrm{C}$, is noticeably lower than the temperatures in the centrifuge, which are minus 1 - minus $2^{\circ} \mathrm{C}$ (see Table 2). Obviously, this is due to the fact that the removal of the crystalline phase from the volume of the tubes into the sediment does not occur in 15 min (time of centrifuging), but much faster. A further increase in temperature in the tubes has little effect on the cloud point of DDF due to the low contact surface of the formed sediment of paraffin and DDF located in the upper part of the tubes.

Dewaxing of MDF when adding to it from 0.1 to $1.0 \%$ wt. of depressant additive DP5/17 at the same rotor speeds from 3000 to $9000 \mathrm{rpm}$ positively affects the performance of the process. The best results are obtained with the lowest content of the additive in MDF $-0.1 \%$ wt. and at a rotor speed of $7000 \mathrm{rpm}$. The yield of DDF reaches $85.0 \%$ wt., and its cloud point is minus $10^{\circ} \mathrm{C}$. Good results on the yield of DDF and its cloud point are also obtained at a rotor speed of $8000 \mathrm{rpm}$ (see table 2). Note the general patterns of MDF dewaxing in the presence of a depressant additive. An increase in the content of depressant additive in the initial fuel and an increase or decrease in the rotational speed of the centrifuge rotor relative to the optimal 7000-8000 rpm leads to a deterioration in its dewaxing parameters.

Increasing the rotor speed to $9000 \mathrm{rpm}$ worsens dewaxing due to excessive heating of the air in the centrifuging zone, and lowering the centrifuge rotor speed reduces the DDF yield and increases its cloud point. The distribution of $\mathrm{n}$-alkanes in DDF according to chromatography relative to the initial MDF (Figure) under optimal conditions (experiment No.ll) shows that the changes in the hydrocarbon composition are insignificant. The maximum content of $\mathrm{n}$-alkane $\mathrm{C}_{14}$ in $\mathrm{DDF}$ is shifted relative to the maximum content in the initial fuel $\left(\mathrm{C}_{15}\right)$ by only one carbon atom. There are two peaks in the paraffin concentrate - with a maximum on docosane (C22) and tetradecane (C14), 
REVISTA DE LA UNIVERSIDAD DEL ZULIA. 3ª época. Año $11 N^{\circ}$ 29, 2020

Nikolay S. Yakovlev et al. /// Improving the cold flow properties ...24-33

i.e. the shift in the highest melting $\mathrm{n}$-alkane relative to tetradecane is 8 carbon atoms (see Figure).

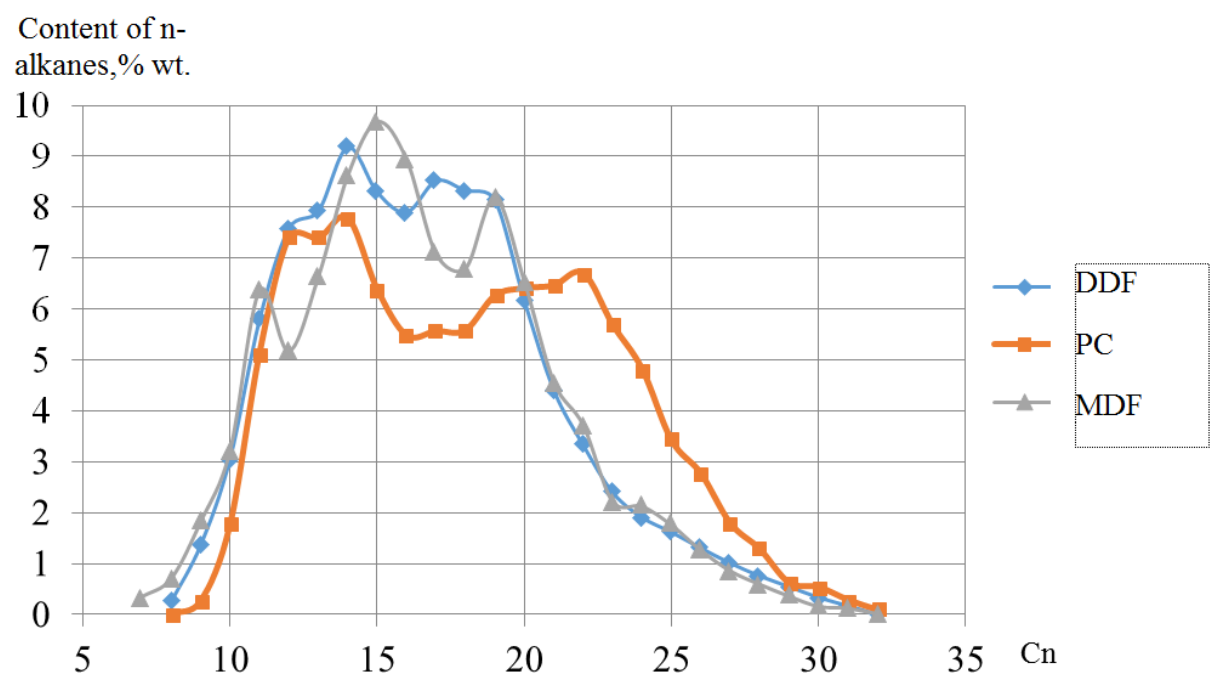

Figure. Distribution of $\mathrm{n}$-alkanes in marine diesel fuel and in dewaxed diesel fuel and paraffin concentrate derived from it

\section{Discussion}

To assess the influence of the centrifuging parameters on the quality indicators of the obtained paraffin concentrate (PC), additional dewaxing of the initial fuel was carried out under optimal conditions. The following initial parameters of the raw material centrifugation were adopted: the initial cooling temperature of the initial fuel before centrifuging $t_{i n}$ - minus $10^{\circ} \mathrm{C}$; temperature of a cryostat integrated in a centrifuge $t_{c r}$ minus $10^{\circ} \mathrm{C}$; centrifuging time $\tau 15 \mathrm{~min}$; rotor speed - $7000-8000 \mathrm{rpm}$, content of the additive in the initial fuel from $0.1 \%$ wt. up to $1.0 \%$ wt. According to the results of centrifuging, the refractive index of paraffin concentrates does not change significantly in the range from 1.4628 to 1.4637 (Table 3), i.e. the introduction of the additive in diesel fuel has little effect on the refractive indices of the resulting paraffin. The melting point of paraffin concentrates obtained after centrifugation with increasing additive content in the feedstock increases markedly - from 25 to $35^{\circ} \mathrm{C}$. To exclude the possible effect of the depressant additive DP-5/17, whose dropping point is $72^{\circ} \mathrm{C}$, on the melting points of paraffin concentrates, the latter were purified from impurities of the polar additive on silica gel. The melting points of paraffin concentrates after purification on silica gel decreased by $9-16^{\circ} \mathrm{C}$ (see Table 3). The slower increase in the melting points of paraffin concentrates before purification on silica gel with an additive content of more than 
$0.5 \%$ wt. in the feedstock is obviously associated with a limited adsorption capacity of paraffin crystals formed in diesel fuel when it is cooled. The obtained results confirm the literature data on the adsorption of depressant additives on solid petroleum hydrocarbons (Savchenkov, Agaev, 1991).

Table 3 - The effect of the centrifuge rotor speed and the content of depressant additive DP-5/17 in the initial fuel on the quality indicators of paraffin concentrate (PC)

\begin{tabular}{|c|c|c|c|c|c|c|}
\hline \multirow{2}{*}{\multicolumn{2}{|c|}{$\begin{array}{c}\text { Centrifuging } \\
\text { parameters }\end{array}$}} & \multicolumn{4}{|c|}{$\begin{array}{l}\text { Indicators of paraffin concentrate quality } \\
\text { after }\end{array}$} & \multirow{3}{*}{$\begin{array}{l}\text { Difference in PC } \\
\text { melting points before } \\
\text { and after purification } \\
\text { on silica gel, }{ }^{\circ} \mathrm{C}\end{array}$} \\
\hline & & \multicolumn{2}{|c|}{ centrifugation } & \multicolumn{2}{|c|}{$\begin{array}{l}\text { centrifugation and } \\
\text { purification on silica } \\
\text { gel }\end{array}$} & \\
\hline $\begin{array}{c}\omega_{r} \\
\mathrm{rpm}\end{array}$ & $\begin{array}{l}C_{\mathrm{DA}}, \\
\% \mathrm{wt}\end{array}$ & $t_{\mathbf{m}},{ }^{\circ} \mathrm{C}$ & $n_{D}^{35}$ & $t_{m},{ }^{\circ} \mathrm{C}$ & $n_{D}^{35}$ & \\
\hline \multirow{3}{*}{7000} & 0.1 & 26 & 1.4631 & 17 & 1.4630 & 9 \\
\hline & 0.5 & 34 & 1.4635 & 18 & 1.4630 & 16 \\
\hline & 1 & 35 & 1.4636 & 20 & 1.4632 & 15 \\
\hline \multirow{3}{*}{8000} & 0.1 & 25 & 1.4628 & 16 & 1.4628 & 9 \\
\hline & 0.5 & 34 & 1.4635 & 20 & 1.4630 & 14 \\
\hline & l & 35 & 1.4637 & 22 & 1.4632 & 13 \\
\hline
\end{tabular}

See constant centrifuging parameters in the text

Designations: $\omega_{\mathrm{r}}-$ centrifuge rotor speed, $\mathrm{rpm} ; \mathrm{C}_{\mathrm{DA}}-$ content of the additive in the feedstock; $\mathrm{t}_{\mathrm{m}}$ - PC melting point.

Conclusion

Thus, it is shown that the centrifugation of marine diesel fuel with an initial cloud point of $1^{\circ} \mathrm{C}$ at a rotor speed of $7000 \mathrm{rpm}$ allows obtaining diesel fuel with a cloud point of minus $8^{\circ} \mathrm{C}$ and a yield of $83.8 \% w t$. Introduction to the original fuel of $0.1 \%$ wt. depressant additive can increase the yield of dewaxed diesel fuel when centrifuging up to $85 \%$ wt. and lower its cloud point to minus $10^{\circ} \mathrm{C}$. The summer diesel fuel obtained at optimal parameters in its cold flow properties corresponds to grade D according to EN 590:2009.

\section{Acknowledgments}

This work was carried out as part of the state task of the Ministry of Education and Science of Russia under project No. 10.7709.2017 / 8.9 "Development of processes for dewaxing oil products in an electric field". 
REVISTA DE LA UNIVERSIDAD DEL ZULIA. $3^{2}$ época. Año 11 N² 29, 2020

Nikolay S. Yakovlev et al. /// Improving the cold flow properties ...24-33

\section{References}

Agaev S. G., Gultyaev S. V., Yakovlev N. S. (2007). Improving the cold flow properties of diesel fuels. Journal of Applied Chemistry, 80(3): 488-495.

Agaev S. G., Yakovlev N. S., Schipanov V. P. (2008). Improving the cold flow properties of summer diesel fuel at the Achinsk oil refinery. News of higher educational institutions. Oil and gas, $4: 68-72$.

Agaev S. G., Yakovlev N. S., Stolbov A. A. (2012). The effect of higher fatty alcohols on the performance of the process of electrical dewaxing of summer diesel fuel. Neftepererabotka i neftekhimiya [Oil refining and petrochemicals], 6: 22-25.

Agaev S. G., Yakovlev N. S., Zima E. U. (2012). Method for oil dewaxing. Patent 2458970 RF, 22458970 RF, IPC ClOG 73/30 (2006.01) ClOG 32/02 (2006.01) RU $20458970 \mathrm{Cl}$. Applied (Application number 2011126199/04) June 24, 2011. Issued August 20, 2012, Bulletin No. 23.

Chernozhukov N. I. (1978). Oil and gas processing technology. Part 3. Moscow: Khimiya [Chemistry]: 423.

García, C.; Martínez, K.; Joves, V.; González, J.; Andarcia, F. (2011). Caracterización viscosa de mezclas de carbón mineral-agua y cenizas volantes-agua mediante fluidización en medio acuoso, Revista de la Universidad del Zulia, 2 (2), 82-99.

Savchenkov A. L., Agaev S. G. (1991). On the distribution of ester depressant additives in oil raffinate. Khimiya i Tekhnologiya Topliv i Masel [Chemistry and Technology of Fuels and Oils], 5: 29-30.

Yakovlev N. S., Agaev S. G. (2012). Dewaxing of summer diesel fuel in a constant electric field. News of higher educational institutions. Oil and gas, 5: 97-10l.

Yakovlev N. S., Agaev S. G. (2017). Dewaxing of heavy weight fractional diesel fuel in an electric field. Khimiya i Tekhnologiya Topliv i Masel [Chemistry and Technology of Fuels and Oils], 3: 38-42. 